IRA-International Journal of Education \&

Multidisciplinary Studies

QUARTERLY

ISSN 2455-2526; Vol.16, Issue 03 (July-Sep, 2020)

Pg. no. 143-154.

Institute of Research Advances

https://research-advances.org/index.php/IJEMS

\title{
Rhythm Reproduction in English Translation of Chinese Poetry: A Contrastive Analysis of Li Bai's "GUAN SHAN YUE" (关山月) and its English Version
}

\author{
Yilu Luo" ${ }^{1 \#}$, Honghui Tan ${ }^{2}$ \\ ${ }^{1,2}$ School of Foreign Studies, Yangtze University, Hubei, 434023 PRC China.
}

\# corresponding author

Type of Work: Peer-Reviewed

DOl: http://dx.doi.org/10.21013/jems.v16.n3.p3

\section{How to cite this paper:}

Luo, Y., Tan, H. (2020). Rhythm Reproduction in English Translation of Chinese Poetry: A Contrastive Analysis of Li Bai's “GUAN SHAN YUE” (关山月) and its English Version. IRA International Journal of Education and Multidisciplinary Studies (ISSN 2455-2526), 16(3), 143-154. DOI: http://dx.doi.org/10.21013/jems.v16.n3.p3

(C) Institute of Research Advances.

This work is licensed under a Creative Commons Attribution-NonCommercial 4.0 International License subject to a proper citation to the publication source of the work.

Disclaimer: The scholarly papers as reviewed and published by the Institute of Research Advances (IRA) are the views and opinions of their respective authors and are not the views or opinions of the IRA. The IRA disclaims of any harm or loss caused due to the published content to any party.

Institute of Research Advances is an institutional publisher member of Publishers International Linking Association Inc. (PILA-CrossRef), USA. The institute is an institutional signatory to the Budapest Open Access Initiative. Hungary advocating the open-access of scientific and scholarly knowledge. The Institute is a registered content provider under Open Access Initiative Protocol for Metadata Harvesting (OAI-PMH).

The journal is indexed \& included in WorldCat Discovery Service (USA), CrossRef Metadata Search (USA), WorldCat (USA), OCLC (USA), Open J-Gate (India), EZB (Germany) Scilit (Switzerland), Airiti (China), Bielefeld Academic Search Engine (BASE) of Bielefeld University, Germany, PKP Index of Simon Fraser University, Canada. 


\begin{abstract}
This paper contrasts the rhythm of Li Bai's “GUAN SHAN YUE” (关山月) and that of Fletcher's English version "The MOON OVER The PASS" and finds out the functional equivalence between the Ping (平) and Ze (不) (level and oblique tones) of Chinese poetry and the lightly stressed and heavily stressed syllables of English poetry, the number of Yan (言) (the number of characters) and the number of feet, and the rhymes. To promote the realization of musical beauty, formal beauty and emotional expression in the translation of Chinese poetry and reproduce the rhythm of ancient Chinese poetry, five-character and seven-character poem with regular line can be translated into iambic pentameter; pre-Tang poem and Song $\mathrm{Ci}$ with irregular line can be translated according to the analogy of character and syllable, and the feet of the translated poem can mainly be iambs; the rhyme of the translated poem can be couplet rhyme, cross rhyme or alternate rhyme. Based on this strategy, the author translates her self-created poem "MAN JIANG HONG ZHAN YI" (满江红・战疫) into English to prove the feasibility of the rhythm reproduction strategy of the English translation of ancient Chinese poetry.
\end{abstract}

Keywords: Poetry; rhythm contrast; translation strategy

\title{
1. Introduction
}

Rhyme and metre are two of the basic aesthetic characteristics of poetry in various countries [1]. In classical Chinese poetry, they are expressed in rhyming rules and the Ping (平) and Ze (大) (level and oblique tones), while in English poetry, they are shown as regular metre and rhyme [2, 3].

Many scholars have made contrastive studies on the rhythm of ancient Chinese poems and their English versions, whose research objects include Book of Songs (Shi Jing), Songs of Chu (Chu Ci), Tang and Song poetry, and even new poetry [4-9]. There are many pieces of research on Tang poetry and its translation, among which Li Bai's works occupy an important position. In the contrastive studies of the rhythms of Li Bai's poems and their translations, the research focuses on “JING YE SI”（静夜 思）, “YUE XIA DU ZHUO”（月下独酌） and “SONG YOU REN”（送友人）, with little attention paid to “GUAN SHAN YUE" (关山月) [10-17]. In fact, the melancholy, resentment, and lovesickness between the soldiers sent on an expedition and their wives is a major theme of Li Bai's poems on the frontier fortresses, among which "GUAN SHAN YUE" is the representative work [18]. It conforms to the rhythm of classical Chinese poetry and is easy to analyze and understand. Therefore, this paper takes Li Bai's “GUAN SHAN YUE” and its English version as a research object.

Translation of rhythm is very difficult, but it is still feasible [19]. At present, many scholars have affirmed the importance of rhythm translation and some of them have put forward corresponding translation standards [20-25]. Only a few scholars have put forward translation strategies of poetry rhythm in practice, but with little universality. Taking Li Bai's "GUAN SHAN YUE” and William John Bainbridge Fletcher's English version "THE MOON OVER THE PASS" as examples, this paper contrasts the rhythm of English poetry and that of Chinese poetry and tries to put forward more universal translation strategies of rhythm reproduction, to provide a reference for the realization of musical beauty, formal beauty and emotional expression of Chinese poetry.

\section{Contrastive Analysis of Rhythm of "GUAN SHAN YUE” and Fletcher's English Version}

\subsection{English Translation of "GUAN SHAN YUE"}


There are at least 19 English versions of "GUAN SHAN YUE" written by Li Bai, including the versions of Witter Byner, William John Bainbridge Fletcher, David Hinton, Shigeyoshi Obata, Sun Dayu, Tang Yihe, Wang Yushu, Wu Juntao, Xu Zhongjie, Xu Yuanchong, Yang Xianyi and Gladys Yang, and so on [26]. Among them, Fletcher is one of the representative translators of metrical poetry. He translated Tang poetry according to the popular English poetry style in the Victorian era. His translation introduced Tang poetry as a whole to British and American readers for the first time, which had a great impact [27-28]. However, the researches on Fletcher's translated poems mainly focus on the translation of “JING YE SI", “BING CHE XING”（兵车行）, “CHANG HEN GE”（长恨歌）, and "SONG YOU REN", and there are few studies on "GUAN SHAN YUE" [29-32]. Therefore, this paper chooses Fletcher's version which conforms to the rhythm of English poetry as the research object.

"GUAN SHAN YUE" describes the scenery of the frontier fortress and the experiences of the soldiers of the garrison and further turns into the pain of lovesickness between the soldiers and their wives. The first four lines depict the landscape of the frontier fortress, including the image of Guan (frontier), the image of Shan (mountain), and the image of Yue (moon); the middle four specifically describe the tragic and cruel battlefield; the last four describe the soldiers' yearning for their hometown and their wives' sigh in the moon night.

$\begin{array}{ll}\begin{array}{l}\text { The original poem and translation are as follows: } \\ \text { 关山月 }\end{array} & \text { THE MOON OVER THE PASS } \\ \text { 明月出天山, } & \text { O'er Altai’s range the Moon arises bright, } \\ \text { 苍茫云海间。 } & \text { Floating in vasty seas of cloud and night. } \\ \text { 长风几万里, } & \text { O'er boundless plains the shrill wind hither blows. } \\ \text { 吹度玉门关。 } & \text { And whistles as o'er Yü -men Pass it goes. } \\ \text { 汉下白登道, } & \text { Beneath the Milky Way there stretches white } \\ \text { 胡窥青海湾。 } & \text { The road that leads to yonder tower-crowned height. } \\ \text { 由来征战地, } & \text { The eager Tatars search each hollow bay } \\ \text { 不见有人还。 } & \text { Of Tsaidam's sea. Nor see I come away } \\ \text { 戌客望边色, } & \text { One mortal soul of all who went to fight. } \\ \text { 思归多苦颜。 } & \text { They dwell in arms; and backward gazing pine } \\ \text { 高楼当此夜, } & \text { For frontier towns; and longing to return } \\ \text { 叹息未应闲。 } & \text { O’er sad worn faces draws a bitter line. } \\ & \text { To-night, as from this lofty tower I yearn, } \\ & \text { No voice reëchoes back these sighs of mine. } \\ & \text { (translated by W.J.B Fletcher [33]) }\end{array}$

\subsection{Contrastive Analysis of Rhythm of "GUAN SHAN YUE" and its English Version}

Rhythm roughly has three elements: metrical pattern, number of metrical patterns, and rhyme. The special emphasis on rhyme and metrical pattern is a unique phenomenon in Chinese verse [34]. In English poetry, the metrical pattern refers to the position of lightly stressed and heavily stressed syllables; the number of metrical patterns refers to the number of feet per line, and the combination of light and stressed syllables is the feet; the rhyme refers to the rhyming rules, and the rhyme of English poetry is more diverse. In Chinese poetry, the metrical pattern refers to the level and oblique tones; the number of metrical patterns is the number of Chinese characters per line; the rhyme is also the rhyming 
rules, and the rhyme of Chinese poetry is relatively simple.

2.2.1 Contrast between Metrical Patterns of Li Bai's “GUAN SHAN YUE” and Fletcher's English Version

\subsubsection{Ping and Ze (Level and Oblique Tones) of "GUAN SHAN YUE"}

In Chinese poetry, the metrical pattern represents the tones of the Chinese characters, which can be classified as Ping and $\mathrm{Ze}$ (level and oblique tones). And Chinese poetry is particular about the harmony of Ping and Ze [35].

The Ping and Ze of "GUAN SHAN YUE” are shown as follows:

平大平平平, 平平平人平。

平平人人, 平入人平平。//

人久平平大, 平平平人平。

平平平人, 平入人平平。//

人久久平入, 平平平人平。

平平平人, 大平大平平。

As mentioned above, every four lines in Guan Shan Yue are divided into one stanza, from which it could be found that the arrangements of Ping and $\mathrm{Ze}$ in each stanza are almost the same. Also, the arrangements still reserve differences, such as the first lines of stanza 2 and stanza 3 and the last line of stanza 3. The poem depicts the scenery of the frontier fortress. With the change of the scene, it reveals the experience of the soldiers of the garrison, and further turns into the pain of missing each other between the soldiers and their wives. With the deepening of emotion, there are more oblique tones in the last two stanzas, from seven oblique tones in stanza 1 to eight and nine in the last two stanzas, which makes the lovesickness and grief of the whole poem gradually intense.

\subsubsection{Lightly Stressed and Heavily Stressed Syllables of Fletcher's English Version}

English verse is a succession of syllables. Some are strongly emphasized, some are not. The metrical patterns are termed "feet", which means heavily stressed syllables are interspersed with more lightly stressed syllables [36].

This paper marks heavily stressed syllables in bold and divides the feet of "THE MOON OVER THE PASS" as follows:

O'er Altai's range the Moon arises bright,

Floating in vasty seas of cloud and night.

O'er boundless plains the shrill wind hither blows.

And whistles as o'er Yü-men Pass it goes.

Beneath the Milky Way there stretches white

The road that leads to yonder tower-crowned height.

The eager Tatars search each hollow bay

Of Tsaidam's sea. Nor see I come away

One mortal soul of all who went to fight.

They dwell in arms; and backward gazing pine

For frontier towns; and longing to return

O'er sad worn faces draws a bitter line. 
To-night, as from this lofty tower I yearn,

No voice reëchoes back these sighs of mine.

It can be seen that the feet of "THE MOON OVER THE PASS" are mainly iambs, namely a lightly stressed syllable followed by a stressed syllable per foot. Through reading the whole poem, the syllables are transferred alternately, which makes the poem have a strong sense of rhythm. It tells the story of soldiers separated from their families and even died to protect their country. The stressed syllable at the end of each line is melancholy, especially the last line "No voice reëchoes back these sighs of mine".

In short, the foundations of the metrical patterns of Chinese and English poetry are different. The metrical pattern of Chinese poetry is in accordance with tone, while that of English poetry is in accordance with stress. However, Ping \& Ze and lightly stressed syllable \& heavily stressed syllable can form a difference in tone and stress, and both the regular arrangements of Ping and Ze and the regular combinations of lightly stressed and heavily stressed syllables can form a difference in sound, so the metrical pattern of Chinese poetry is functionally equivalent to that of English poetry.

2.2.2 Contrast between Numbers of Metrical Patterns of Li Bai's "GUAN SHAN YUE" and Fletcher's English Version

\subsubsection{The Number of Yan (言) of “GUAN SHAN YUE”}

Chinese characters are monosyllabic, so the number of metrical patterns in Chinese poetry is the number of characters, also known as "Yan", from which the types of Chinese poetry can be judged. Taking the Tang Dynasty as the boundary, from the Book of Songs to poetry in the Southern and Northern Dynasties are all pre-Tang poetry or ancient poetry; the new types after the establishment of the Tang Dynasty are all "modern style" poetry. Pre-Tang poetry is with fixed lines and styles, but fewer restrictions on its rhythm, including four-character, five-character, seven-character, and miscellaneous language poems, compared with "modern style" poetry, which has strict requirements on rhythm, mainly including Tang poetry, Song $\mathrm{Ci}$, and Yuan Qu.

"GUAN SHAN YUE" is a five-character ancient poem with twelve lines in total. It belongs to the old title of Yuefu, a government office in the Han Dynasty (206 B.C.-A.D.220) for collecting folk songs and ballads, and is military music played on horses with ancient battle drums and horns. It expresses the sadness of parting, as Explanation of Ancient Title of Yuefu said: "GUAN SHAN YUE is the pain of parting" [37].

\subsubsection{The Number of Feet in Fletcher's English Version}

In English poetry, the number of metrical patterns is expressed as the number of feet. The type and number of feet in a line is called the metre of the line. The number of feet in a line starts from one and usually does not exceed nine. Among them, the pentameter line is the most frequently used, and the iambic pentameter line, also known as the heroic verse line, occupies a dominant position in English poetry $[38,39]$. The common types of English poetry include the ballad metre, the sonnet, the blank verse, the heroic couplet, the terza rima, the ode, and variants of the above [40].

The metre of "THE MOON OVER THE PASS" is divided as follows: 
O'er Al//tai's range// the Moon //ari//ses bright,

Floating// in va//sty seas //of cloud// and night.

O'er bound//less plains //the shrill //wind hi//ther blows.

And whi//stles as //o'er Yü// -men Pass// it goes.

Beneath //the Mil//ky Way //there stre//tches white

The road// that leads //to yon//der tow//er-crowned height.

The ea//ger Ta//tars search //each ho//llow bay

Of Tsai//dam's sea. //Nor see //I come //away

One mor//tal soul //of all //who went// to fight.

They dwell //in arms; //and back//ward ga//zing pine

For fron//tier towns; //and long//ing to //return

O’er sad// worn fa//ces draws //a bi//tter line.

To-night, //as from//this lof//ty tow//er I yearn,

No voice //reë//choes back //these sighs// of mine.

It can be seen that "THE MOON OVER THE PASS" is composed of five feet per line, and each foot is mainly composed of lightly stressed syllable and heavily stressed syllable to form the iambic. The whole poem rhymes according to certain rules. Therefore, it should be a metrical poem with iambic pentameter. There are 14 lines in the poem, but they are not rhymed according to $a b b a a b b a c d c$ $d c d$ or $a b a b c d c d$ efef $g g$, so the poem does not belong to the sonnet.

From the above, it can be found that there are differences in the scales of Yan and foot. In Chinese poetry, Yan refers to the Chinese characters in each line, while in English poetry, foot refers to the combination of lightly stressed and heavily stressed syllables. However, both Yan and foot are the rhythm unit of poetry. Also, the type of Chinese poetry can be judged from the Ping and Ze and the number of Yan, and the type of English poetry can be judged from the type and the number of feet. Therefore, Yan and feet have the same function.

2.2.3 Contrast between Rhymes of Li Bai’s "GUAN SHAN YUE” and Fletcher's English Version 2.2.3.1 Rhyme of "GUAN SHAN YUE”

Rhyme in Chinese poetry refers to the use of characters with the same or similar compound vowels at the end of most lines in a poem, which produces the beauty of rhythm. The rules of rhyme in pre-Tang poetry are relatively loose, which can change rhyme and use similar rhyme. But the rhyme of a "modern style" poem has strict rules: to rhyme in even-numbered lines; to use flat tone; to never change rhyme. However, it is not advisable to destroy the content of the poem to accommodate rhyme, so it is allowed to change rhyme in one or two lines.

In “GUAN SHAN YUE”, the “山 Shan” at the end of the first line and “间 Jian”, “关 Guan”, “湾 Wan”, “还 Huan”, “颜 Yan” and “闲 Xian” at the end of even-numbered lines all take “an” as their compound vowel, that is, "an" as the rhyme. Although "GUAN SHAN YUE" belongs to the pre-Tang poetry, Li Bai's rhyme is in line with the strict rhyming rules of "modern style" poetry, which means to rhyme in even-numbered lines, to use flat tone, and never change rhyme. So, it is with the beauty of rhyme. 


\subsubsection{Rhyme of Fletcher's English Version}

Rhyme in English poetry, in short, is to put words or syllables with the same vowel at the end of the line, namely the exact echoing of a sound at the end of one line by the sound at the end of another line [41, 42]. However, if two lines end in the same word, they do not rhyme. The rhymes of English poetry include monosyllabic rhyme, disyllabic rhyme, and trisyllabic rhyme. Among them, monosyllabic rhyme is the most widely used, while disyllabic rhyme and trisyllabic rhyme are seldom used. In a poem, monosyllabic rhyme is usually mixed with monosyllabic rhyme [43]. In addition, in an English poem, the rhyme is not consistent but can be in accordance with aabb, abab, abba, and so on.

In "THE MOON OVER THE PASS", The words at the end of the line are bright, night, blows, goes, white, height, bay, away, fight, pine, return, line, yearn, and mine, whose rhymes are respectively /ait/ /ait/ /ouz/ /ouz/ /ait/ /ait/ /ei/ /ei/ /ait/ /ain/ /ə:n/ /ain/ /ə:n/ /ain/, namely rhyming according to aabb aacc ade ded, with musical beauty.

It can be seen from the above that although the rhyming rules of English and Chinese poetry are different, they both embody the beauty of music and make poetry easy to sing. Therefore, the rhymes of English and Chinese poetry are functionally equivalent.

\section{Translation Strategies of Rhythm Reproduction}

From the above analysis, it can be found that the Ping and $\mathrm{Ze}$ (level and oblique tones) of Chinese poetry and the lightly stressed and heavily stressed syllables of English poetry are in functional equivalence, so are the number of characters and the number of feet, and the rhymes. Then, in poetry translation, how can we reproduce the rhythm of the original poem?

\subsection{Five-character and Seven-character Poem}

The most common classical Chinese poem is a five-character and seven-character poem, while the most common English metrical poem is iambic pentameter. This paper holds that iambic pentameter can be used to translate the five-character and the seven-character poem. According to the contrast between the rhythm of Li Bai's "GUAN SHAN YUE" and that of Fletcher's translation, it can be seen that to translate the five-character poem with iambic pentameter can fit the rhythm of the original poem and achieve good translation effect. Another example is that Giles translated He Zhizhang's seven-character poem “HUI XIANG OU SHU” (回乡偶书) with iambic pentameter, which not only expresses the meaning of the original poem, but also the musical beauty.

The original poem and the translated poem are as follows:
回乡偶书 THE RETURN
少小离家老大回,
Bowed down// with age// I seek// my na//tive place,
乡音无改䰅毛衰。
Unchanged// my speech//, my hair// is sil//vered now;
儿童相见不相识,
My ve//ry chil//dren do// not know// my face,
笑问客从何处来。
But smi//ling ask//, "O stran//ger, whence// art thou?"
(translated by H. A. Giles [44])

\subsection{Pre-Tang Poem and Song Ci}

The lengths of lines of a pre-Tang poem are different, so are those of a Song Ci, so they can be 
translated according to the analogy of character and syllable. Since a foot in English poetry is usually two syllables, Zhao Yanchun makes the following analogy: three characters to five syllables; four characters to six syllables; five characters to eight syllables; six characters to nine syllables; seven characters to ten syllables; eight characters to twelve syllables; nine characters to fourteen syllables. This setting has been verified in his translation of Li Bai's "SHANG YUN LE", namely Wen K'ang, a Hun. Since most of English poems are iambic, the English translation of Chinese poems should also be dominated by iambic [45]. Of course, the metre of translated poems should also be flexible, allowing the existence of metre variants.

As for the translation of rhyme, Wang Dongfeng thinks that English metrical poetry can have no rhyme, but it cannot be without metre, such as plain verse [46]. However, this paper agrees with Zhao Yanchun's view that the translation of a poem with rhyme must be rhymed and rhythmic, but how to rhyme and what type of rhyme to use vary from person to person. Rhyme of English poetry is not as strict as that of Chinese poetry. The general principle is the harmony of rhyme and metre. Therefore, the translated poem should be rhymed as well as the original poem, which can be used more frequently in the form of couplet rhyme, cross rhyme, or alternate rhyme [47].

In 2020, COVID-19 is rampant in the world. As the main battlefield to fight against the epidemic, Wuhan has overcome many difficulties and gradually won the victory. To commemorate the heroic city of Wuhan and the great contribution made by the people all over the world to the fight against the epidemic, the author created a poem "MAN JIANG HONG ZHAN YI", which was translated into English according to the rhythm reproduction strategy of Song Ci, to verify the feasibility of the rhythm reproduction strategy above.

The original and translated poems are as follows:

\begin{tabular}{|c|c|}
\hline 满江红・战疫 & Tune: The River All Red --To Overcome COVID-19 \\
\hline 遥望江城, & Wuhan, //from seen// afar, \\
\hline 无声寂、 & The si//lent ci//ty is, \\
\hline 今当国难。 & In $\mathbf{a} / / \mathrm{pande} / / \mathrm{mic}$ war. \\
\hline 昔繁华， & In flou//rishing past, \\
\hline 珞珈 ${ }^{1}$ 书朗, & At Luo//jia ${ }^{1}$ rea//ding spread. \\
\hline 晴川 ${ }^{2}$ 韶慢。 & In Qing//chuan ${ }^{2}$ slowed// time tread. \\
\hline 流水古琴 ${ }^{2}$ 知已乐, & For friend//ship ba//bbling Gu//qin ${ }^{2} \mathrm{did} / /$ remain. \\
\hline 高楼黄鹤 ${ }^{2}$ 身姿曼。 & High to//wer kept// lithe grace// of Ye//llow Crane ${ }^{2}$. \\
\hline 现如今, & Howe//ver, these days, \\
\hline 妖雾笼城池， & The ci//ty e//vil smoke// invades. \\
\hline 萧然满。 & Prospe//rity fades. \\
\hline 三山起 ${ }^{3}$, & Three Moun//tains ${ }^{3}$ raising, \\
\hline 天下叹。 & Whole world// highly praise. \\
\hline 三平 ${ }^{4}$ 至, & Coming// Three Peaces ${ }^{4}$ \\
\hline 人间赞。 & Earthling// is appeased. \\
\hline 看娟兰 ${ }^{5}$ 盛放, & We ten//der or $/ /$ chids $^{5}$ bloo//ming cheer. \\
\hline 冠妖皆散。 & All demons// disappear. \\
\hline 白衣逆行担重任, & Bear hea//vy load// Counter//marching// white gown \\
\hline
\end{tabular}


绿装前进擒毒冠。 Advan//cing sol//diers press// the vi//rus down.

待春还,

与尔泛东湖 ${ }^{6}$,

繁花漫!
After spring// returns,

Toge//ther tour// East Lake $\mathbf{~}^{6} / /$ not why?

Flowers fill// our eyes!

1. 珞珈: 珞珈山, 武汉大学、周恩来故居以及郭沫若、郁达夫、蒋介石别墅都坐落在此。

2. 晴川、古琴、黄鹤: 晴川阁、古琴台、黄鹤楼并称武汉三大名胜。

3. 三山: 火神山, 雷神山, 钟南山院士。

4. 三平: 家太平, 国太平, 天下太平。

5. 娟兰: 姿态柔美的兰草, 致敬李兰娟院士。

6. 东湖: 武汉东湖风景区, 是中国第二大的城中湖, 武汉大学、华中科技大学和中国地质大学 (武汉)、武汉体育学院等全国重点大学坐落在东湖湖畔。

1. Luojia Mountain is famous for its scenic spots. including Zhou Enlai's former residence, Guo Moruo's, Yu Dafu's, and Chiang Kai Shek's villas. And Wuhan University, a famous institution of higher education in China, is also located here.

2. Guqin, Yellow Crane, and Qingchuan Pavilion refer to the three most famous historical relics in Wuhan, namely Guqin Platform, Yellow Crane Tower, and Qingchuan Pavilion.

3. Three Mountains refer to Leishenshan Hospital, Huoshenshan Hospital, and Zhong Nanshan, a member of Chinese Academy of Engineering and a prominent expert in respiratory diseases, as "mountain" are read as "shan" in Chinese.

4. Three Peaces refer to the peace of the family, the peace of the country, the peace of the world.

5. Tender orchids here symbolize Li Lanjuan, an epidemiologist and a member of the high-level expert team on the novel coronavirus convened by the National Health Commission, as tender orchids and Lanjuan have a similar meaning.

6. East Lake is the second largest lake in the city in China. Many Chinese famous universities are located by East Lake, including Wuhan University, Huazhong University of Science and Technology, China University of Geosciences (Wuhan), Wuhan Institute of Physical Education, etc.

\section{Conclusion}

By contrasting the prosodies of Li Bai's "GUAN SHAN YUE" and Fletcher's English version, this paper finds out the functional equivalence between the Ping and $\mathrm{Ze}$ (level and oblique tones) of Chinese poetry and the lightly stressed and heavily stressed syllables of English poetry, the number of Yan (the number of character) and the number of feet, and the rhymes. Ping and Ze are functionally equivalent to lightly stressed and heavily stressed syllables, as Ping \& Ze and lightly stressed \& heavily stressed syllables can form a difference in tone and stress, and both the regular arrangement of Ping and $\mathrm{Ze}$ and the regular combination of lightly stressed and heavily stressed syllables can form rhythm; the number of Yan is functionally equivalent to the number of feet, as both Yan and foot can form the rhythm unit of poetry, although their scales are different; the rhyme of Chinese poetry is functionally equivalent to that of English poetry, as they both embody the musical beauty and make poetry easy to sing, although the rhyming rules of English and Chinese poetry are different. Therefore, the rhythm of English poetry is the closest natural equivalence to that of Chinese poetry.

Fletcher's English version "THE MOON OVER THE PASS" does not copy the original rhythm but conforms to that of English poetry, which can fit the musical and emotional characteristics of the 
original poem and makes the translation reach an overall aesthetic agreement with the original poem and have a good translation effect. Consequently, the translated poem should be rhymed as well as the original poem, and the rhythm of the original poem should be reproduced in the translated poem.

To improve the quality of Chinese poetry translation and promote the realization of musical beauty and formal beauty, this paper puts forward the translation strategies of rhythm reproduction: five-character and seven-character poem with regular line can be translated into iambic pentameter; pre-Tang poem and Song Ci with irregular line can be translated according to the analogy of character and syllable (three characters to five syllables; four characters to six syllables; five characters to eight syllables; six characters to nine syllables; seven characters to ten syllables; eight characters to twelve syllables; nine characters to fourteen syllables), and the feet of the translated poem can mainly be iambs; the rhyme of the translated poem can be couplet rhyme, cross rhyme or alternate rhyme. In memory of the great contribution of Wuhan and the people all over the world in fighting against COVID-19, the author translated her self-created poem "MAN JIANG HONG ZHAN YI"（满江 红 - 战疫) into English according to the rhythm reproduction strategies of Song Ci, to verify the feasibility of the strategy.

Funding: Research for this article was funded by the Hubei Provincial Fund Project of Humanities and Social Sciences, P. R. China (Study on the Translation of $\mathrm{Chu} C i$ and the Image Construction of Pre-historic China, No. 18D027).

\section{References:}

[1] Huang, Xinqu. (1992). Comparison and Translation of Rhythms of Chinese and English Poetry. Journal of Foreign Languages, (4), 54-59. P54.

[2] Huang, Jianhua. (1979). A Layman Talking about the Rhythm of Poems-Discussing with Mr. Gui Cankun. Modern Foreign Languages, (2), 39-40. P39.

[3] [38] [40] [41] [43] Wu, Xianglin. (1993). The Rhythm of English Poetry and Free Verse. Beijing: Commercial Press. P4, P17-18, P177-212, P8, P104-109.

[4] Si, Xiaocai. (2016). A Comparative Study on Rhythms of Chinese and English Poetry-Taking the Treatment of Rhythm in Different English Versions of Shi Jing Jian Jia as an Example. Modern Chinese, (1), 149- 150.

[5] Jiang, Lin, \& Yu, Yesheng. (2011). On Three Translation Methods of Arthur Waley's Nine Songs. Chinese Translators Journal, (1), 65-67.

[6] Jiang, Shan. (2017). A Corpus-Based Study of Translator's Style in Two English Versions of Du Fu's Poems. Journal of Dufu Studies, (03), 58-65.

[7] Zhou, Fangheng. (2019). A Comparative Study of the Two English Versions of Sheng Sheng Man from the Perspective of the Theory of Optimization of the Target Language. Journal of Southwest University of Science and Technology (Philosophy and Social Science Edition), 36(01),35-39+94.

[8] Cao, Yingchun. (2016). On the Translation of Rhythm of Classical Drama-A Contrastive Analysis of Peony Pavilion. Chinese Translators Journal, (1), 95-99.

[9] Chen, Liming, \& Ma, Shuang. (2018). Interactive Production in Xu Zhimo's Poetic Writing and Translation. Journal of Foreign Languages, 41(3), 86-98.

[10] Li, Meng, \& Wen, Jun. (2011). "On the Translation of Jing Ye Si in China: Comments and Suggestions." Sichuan University of Arts and Science Journal, 21(6),145-148.

[11] Su, Yishan. (1984). On the Gain and Loss of Two English Versions of Li Bai's Jing Ye Si. Journal of Hanshan 
Normal University, (2), 84-86.

[12] [29] Zhao, Zhengtao. (1986). Appreciation of the English Translation of Li Bai's Jing Ye Si. Foreign Language Teaching and Research, (4), 15-18.

[13] Zhang, Jianjia. (2003). Comparison and Comment on the English translation of Jing Ye Si. Journal of Central South University of Forestry \& Technology, (6), 98-101.

[14] Qiu, Ke' an. (1991). On the English Translation of Li Bai's Song You Ren. Foreign Language Teaching and Research, (3), 34-38.

[15] Wu, Yi. (2015). A Comparative Study of Different English Versions of Li Bai's Song You Ren from the Perspective of Relevance Theory. Journal of Language and Literature Studies, (12), 39-41.

[16] Zheng, Xingmao. (2017). An Analysis of the Rhyme and Rhythm and the Artistic Conception of Yue Xia Du Zhuo-Comments on Giles's English Translation. English Square, (1), 18-20.

[17] Li, Yin. (2013). On the realization of style translation in ancient poetry translation-Taking Yue Xia Du Zhuo as an Example. Social Sciences in Hunan, (1), 256-259.

[18] She, Zhengsong. (2005). The History of Classical Chinese Frontier Poetry. Chengdu: Sichuan University.

[19] Walsh, A. S. (2018). Essentially Translatable Poetry-the Case of Lorca's Poet in New York. The Translator, 24(3), 263-274. DOI: 10.1080/13556509.2018.1536307. P264.

[20] Watson, B. (ed). (1984). The Columbia Book of Chinese Poetry: from early times to the thirteenth century. New York: Columbia University Press. P10-13.

[21] Giles, H. A. (ed). (1884). Gems of Chinese Literature. London: Bernhard Quaritch. Preface 5.

[22] Hawkes, D. (1959). Ch'u Tz'u. The Songs of the South: An Ancient Chinese Anthology. Oxford: Clarendon Press. P3-7.

[23] Hawkes, D. (2011). The Songs of the South: An Ancient Chinese Anthology of Poems by Qu Yuan and Other Poets. London: Penguin Books. P14.

[24] Xu, Yuanchong. (2006). The Art of Translation. Beijing: China Intercontinental Press. P 73-81.

[25] Gu, Zhengkun. (2010). China and West: Comparative Poetics and Translatology. Beijing: Tsinghua University Press. P6-40.

[26] [37] Wang, Feng, \& Ma, Yan. (2011). A Critical Anthology of Tang Poems and their English Translations. Xi'an: Shaanxi People's Publishing House. P299, P297.

[27] Wang, Feng. (2015). A Comprehensive Study on the English Translation of Classical Tang Poetry. Beijing: China Social Sciences Press. P20.

[28] Wang, Xiaoke, \& Wang, Zhigeng. (2013). A Revaluation of W. J. B. Fletcher's Contribute to English Translation of Tang Poetry." Literature and Culture Studies, (01),100-108. P100-101.

[30] Wen, Jun, \& Cao, Siqi. (2013). The Comparative Study of Two English Versions of Song of the Conscripts Based on Berman's Theory. The Journal of English Studies, 11(03):48-55.

[31] Geng, Yucong. (2017). Domestication and Foreignization Tendency and Cultural Dissemination in Translating Ancient Chinese Poetry into English - A Case Study of the English Versions of Chang Hen Ge. EDUCATION TEACHING FORUM, (27), 82-83.

[32] Yao, Qiaomei. (2015). On the Main Features of Fletcher's Chinese Poetry Translation. Crazy English (Teachers), (04), 157-160.

[33] Fletcher, W.J.B. (1919). More Gems of Chinese Poetry. Shanghai: The Commercial Press. P14-15.

[34] [35] Zetian, Zongqing, \& Wang, Heyi. (1984). History of Chinese Verse (Volume 1). Shanghai: Shanghai Bookstore. P5, P5-6.

[36] [39] [42] Hobsbaum, P. (2006). Metre, Rhythm and Verse Form. London and New York: Routledge. P1, P1, $\mathrm{P} 27$. 
[44] Giles, H. A. (ed). (1923). Gems of Chinese Literature: Verse (2 ${ }^{\text {nd }}$ ed.). London: Bernhard Quaritch, and Shanghai: Kelly and Walsh. P61.

[45] [47] Zhao, Yanchun. (2019, April 21). On the Formal Requirements of Ancient Poetry Translation [OL]. Language and Translation, from https://mp.weixin.qq.com/s/M2gkcm2o4h_N6D0NfZzB9Q

[46] Wang, Dongfeng. (2019). Retrieving the Lost Musicality: A Study of Rhythmic Sound Pattern in Poetry Translation. Journal of Foreign Languages, 42(01), 72-82+110. P82. 